\title{
Familial sick sinus syndrome
}

INSERM

\section{Source}

INSERM. (1999). Orphanet: an online rare disease and orphan drug data base. Familial sick sinus syndrome. ORPHA:166282

Sick sinus syndrome is a rare cardiac rhythm disease, usually of the elderly, characterized by electrocardiog raphic findings of sinus bradycardia, atrial fibrillation, atrial tachycardia sinus arrest, or sino-atrial block, and that manifest with symptoms like syncope, dizziness, palpitations, fatigue, or even heart failure. It results from malfunction of the cardiac conduction system, probably secondary to degenerative fibrosis of nodal tissue in the elderly or secondary to cardiac disorders in younger patients. 